\title{
Authenticity testing of organically grown vegetables by stable isotope ratio analysis of oxygen in plant-derived sulphate
}

Novak, Vlastimil; Adler, Josefine; Husted, Søren; Fromberg, Arvid; Laursen, Kristian Holst

Published in:

Food Chemistry

Link to article, DOI:

10.1016/j.foodchem.2019.03.125

Publication date:

2019

Document Version

Peer reviewed version

Link back to DTU Orbit

Citation (APA):

Novak, V., Adler, J., Husted, S., Fromberg, A., \& Laursen, K. H. (2019). Authenticity testing of organically grown vegetables by stable isotope ratio analysis of oxygen in plant-derived sulphate. Food Chemistry, 291, 59-67. https://doi.org/10.1016/j.foodchem.2019.03.125

\section{General rights}

Copyright and moral rights for the publications made accessible in the public portal are retained by the authors and/or other copyright owners and it is a condition of accessing publications that users recognise and abide by the legal requirements associated with these rights.

- Users may download and print one copy of any publication from the public portal for the purpose of private study or research.

- You may not further distribute the material or use it for any profit-making activity or commercial gain

- You may freely distribute the URL identifying the publication in the public portal 


\section{Accepted Manuscript}

Authenticity testing of organically grown vegetables by stable isotope ratio analysis of oxygen in plant-derived sulphate

Vlastimil Novak, Josefine Adler, Søren Husted, Arvid Fromberg, Kristian Holst

Laursen

PII:

S0308-8146(19)30611-9

DOI:

https://doi.org/10.1016/j.foodchem.2019.03.125

Reference:

FOCH 24572

To appear in:

Food Chemistry

Received Date:

19 November 2018

Revised Date:

21 March 2019

Accepted Date:

24 March 2019

Please cite this article as: Novak, V., Adler, J., Husted, S., Fromberg, A., Laursen, K.H., Authenticity testing of organically grown vegetables by stable isotope ratio analysis of oxygen in plant-derived sulphate, Food Chemistry (2019), doi: https://doi.org/10.1016/j.foodchem.2019.03.125

This is a PDF file of an unedited manuscript that has been accepted for publication. As a service to our customers we are providing this early version of the manuscript. The manuscript will undergo copyediting, typesetting, and review of the resulting proof before it is published in its final form. Please note that during the production process errors may be discovered which could affect the content, and all legal disclaimers that apply to the journal pertain. 
Title:

Authenticity testing of organically grown vegetables by stable isotope ratio analysis of oxygen in plant-derived sulphate

\section{Authors:}

Vlastimil Novak ${ }^{a}$, Josefine Adler ${ }^{a}$, Søren Husted ${ }^{a}$, Arvid Fromberg ${ }^{b}$ and Kristian Holst Laursen ${ }^{a}$ Corresponding author: Kristian Holst Laursen (holst@plen.ku.dk)

\section{Affiliations:}

a Plant and Soil Science Section and Copenhagen Plant Science Centre, Department of Plant and Environmental Sciences, Faculty of Science, University of Copenhagen, Thorvaldsensvej 40, 1871 Frederiksberg C, Denmark

b National Food Institute, Technical University of Denmark, Kemitorvet, Building 202, 2800 Kgs. Lyngby, Denmark

Key words: Authentication, compound-specific, organic agriculture, plants, stable isotopes, sulphate, vegetables 


\begin{abstract}
Analytical methods for authenticity testing of organically grown vegetables are urgently needed. Here we present a novel method for organic authentication based on stable isotope ratio analysis of oxygen in plant-derived sulphate. We combined this method with stable isotope ratio analysis of bulk plant tissue and plant-derived nitrate to discriminate organic and conventional potato, carrot, and cabbage from rigidly controlled long-term field trials and from a case study using retail potatoes. It was shown that oxygen isotope ratios of sulphate from organic vegetables were significantly lower compared to their conventional counterparts and the values were directly linked to the fertilisation strategy. The classification power of sulphate isotope analysis was superior compared to known bulk tissue isotope markers and nitrate isotope values. In conclusion, oxygen isotope analysis of plantderived sulphate represents a promising new method for authentication of organic vegetables.
\end{abstract}

Highlights

- A method for oxygen isotope ratio analysis of plant-derived sulphate was developed

- Oxygen isotope ratio analysis of sulphate was used for organic authentication

- The novel method was compared to traditional isotope markers

- Oxygen isotope analysis of sulphate was superior for authentication of organic vegetables 


\section{Introduction}

The global market for organic food products is rapidly expanding and increased by almost five-fold between 2000 and 2017 reaching sales of more than 90 billion euros (Lernoud \& Willer, 2019). A high demand for organic products, lower yields in organic plant production and ultimately higher retail prices compared to conventional produce increase the likelihood of fraud and adulteration (Kelly \& Mihailova, 2017; Reganold \& Wachter, 2016). Consequently, the aim of this study is to address an urgent and increasing demand for analytical methods that can verify the authenticity of organic products.

Organic agriculture can be broadly defined as a farming method that aims at promoting responsible use of natural resources, biodiversity and soil fertility (Reganold \& Wachter, 2016). The rules for organic production in the EU are set by the council regulations (EC) No 834/2007, 889/2008 and $1235 / 2008$. These regulations generally prohibit the use of pesticides and synthetic fertilisers in organic agricultural systems. Organic farming maintains soil fertility by use of catch crops, green manures, composts and/or animal manures etc. Compliance with the rules and thereby the authenticity of organic products is assured by accreditation and regular inspections of farmers and products. Revealing of false organic labelling is however difficult due to the complexity of global food supply chains and the lack of analytical methods for organic authentication (Kelly \& Mihailova, 2017). The urgent need for methods to reliably verify the authenticity of organic vegetables has spurred the development of various analytical approaches. Studies focused on multi-element analysis (Laursen, Schjoerring, Olesen, Askegaard, Halekoh, \& Husted, 2011), or pesticide residue analysis have shown limitations in discriminating conventional and organic produce (Devlieghere et al., 2009). Stable isotope ratio mass spectrometry currently constitutes one of the most promising tools (Capuano, Boerrigter-Eenling, Veer, \& Ruth Saskia, 2012; Laursen, Bontempo, Camin, \& 
Roßmann, 2016; Laursen, Schjoerring, Kelly, \& Husted, 2014). Specifically, nitrogen isotope ratios of bulk plant tissue $\left(\delta^{15} \mathrm{~N}_{\text {bulk }}\right)$ and oxygen isotope analysis of plant-derived nitrate $\left(\delta^{18} \mathrm{O}_{\text {nitrate }}\right)$ were previously successfully used for organic plant authentication (Laursen et al., 2013; Mihailova, Pedentchouk, \& Kelly, 2014).

Analysis of $\delta^{15} \mathrm{~N}_{\text {bulk }}$ in plants reflects isotope values of soil nitrogen and can determine sources of nitrogen supplied via different fertilisation strategies (Bateman, Kelly, \& Woolfe, 2007; Camin et al., 2007; Capuano et al., 2012; Choi et al., 2017; Laursen et al., 2013; Schmidt et al., 2005). It is based on the fact that conventional famers often use synthetic nitrogen fertilisers with average $\delta^{15} \mathrm{~N}$ values close to $0 \%$ as nitrogen is fixed from the atmosphere during the Haber-Bosch process, while compost and animal manures used in organic systems range between 4 and $16 \%$ (Bateman \& Kelly, 2007). The higher enrichment of animal manures is mainly caused by fractionation against ${ }^{15} \mathrm{~N}$ during atmospheric loss of nitrogen as ammonia (Bateman \& Kelly, 2007; Choi et al., 2017). As examples, $\delta^{15} \mathrm{~N}_{\text {bulk }}$ was successfully used for discriminating organic and conventional potatoes, tomatoes and lettuces (Bateman et al., 2007; Camin et al., 2007). However, $\delta^{15} \mathrm{~N}_{\text {bulk }}$ cannot distinguish vegetables grown with legume-based organic fertilisers versus synthetic fertilisers, as $\delta^{15} \mathrm{~N}$ values of these fertilisers are often similar due to the atmospheric origin of $\mathrm{N}$ in these. This could lead to organic crops being misclassified as conventional when relying exclusively on this marker (Laursen et al., 2013). Novel and more specific analytical methods are therefore urgently needed.

Recent pilot studies have demonstrated that compound-specific stable isotope ratio analysis is a promising tool for organic authentication. Stable isotope analysis of amino acids was e.g. used for discriminating organic and conventional wheat (Paolini, Ziller, Laursen, Husted, \& Camin, 2015). Another study focused on analysis of plant-derived nitrate (Laursen et al., 2013). A combination of 
$\delta^{18} \mathrm{O}_{\text {nitrate }}$ and $\delta^{15} \mathrm{~N}_{\text {bulk }}$ discriminated potatoes that had been grown with conventional synthetic fertilisers versus organic fertilisers including legume-based green manures. It was suggested that the higher $\delta^{18} \mathrm{O}_{\text {nitrate }}$ values (> $20 \%$ ) of conventional potatoes were caused by the atmospheric origin of oxygen in synthetic nitrate fertilisers while the lower $\delta^{18} \mathrm{O}_{\text {nitrate }}$ values $(<20 \%$ of organic potatoes were caused by oxidation of nitrogen (nitrification) from organic manures prior to plant uptake (Laursen et al., 2013). In another study, both $\delta^{15} \mathrm{~N}_{\text {nitrate }}$ and $\delta^{18} \mathrm{O}_{\text {nitrate could discriminate }}$ greenhouse grown lettuce fertilised with chicken manure or synthetic nitrate fertiliser. Furthermore, there was a difference in $\delta^{18} \mathrm{O}_{\text {nitrate }}$ between conventional and organic retail potatoes as well as tomatoes (Mihailova et al., 2014). In these studies, nitrate was isolated from plants using the denitrifier method (Casciotti, Sigman, Hastings, Böhlke, \& Hilkert, 2002; Sigman, Casciotti, Andreani, Barford, Galanter, \& Böhlke, 2001). However, as this method is labour intensive and costly (Laursen et al., 2013; Mihailova et al., 2014), the implementation of nitrate isotope analysis for organic authentication is still pending.

In this study, we propose a novel isotopic marker for authenticity testing of organically grown vegetables based on compound-specific stable isotope analysis (CSIA), i.e. oxygen isotope ratio analysis of plant-derived sulphate $\left(\delta^{18} \mathrm{O}_{\text {sulphate }}\right)$. We hypothesize that the use of organic versus synthetic fertilisers in vegetable production will lead to different $\delta^{18} \mathrm{O}_{\text {sulphate }}$ values in plants, as the reported $\delta^{18} \mathrm{O}_{\text {sulphate }}$ values for synthetic fertilisers (12 to $15 \%$ o) generally appear to be higher than

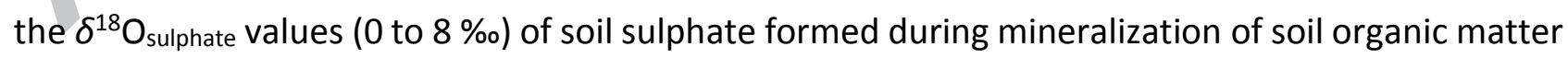
(Mayer, Fritz, Prietzel, \& Krouse, 1995; Vitòria, Otero, Soler, \& Canals, 2004). Thus, our aim was to develop a novel and robust method providing a reliable authentication of organic produce using CSIA. The classification power of the novel method for sulphate isotope analysis was demonstrated using long-term conventional and organic vegetable field trials and compared to existing isotope 
markers. The method was further tested in a case study to authenticate conventional and organic retail potato. 


\section{Materials and Methods}

\subsection{Plant material, fertilisers and sample preparation}

\subsubsection{Field trials}

The field study expanded on previous work published by Laursen et al. $(2011,2013)$. Potatoes (Solanum tuberosum L. cv. Sava) were grown in the long-term crop rotation experiment CropSys (Olesen, Askegaard, \& Rasmussen, 2000). The CropSys experiment was conducted at three different locations in Denmark (Flakkebjerg, Foulum and Jyndevad), including different soil types and climatic conditions. At each location, potatoes were produced in three agricultural systems: one conventional growth system (C) relying on the input of synthetic nitrogen fertilisers and use of pesticides, and two organic agricultural systems (OA, $O B$ ) managed according to the European Union guidelines for organic farming (EC) No 834/2007. The organically grown vegetables were fertilised with animal manure (OA), or by use of green manures and catch crops (OB) and harvested in years 2007 and 2008. Due to complexity of the experimental setup and the fact that several research projects relied on plants from the CropSys project, only two field replicates were possible. Therefore, large field plots $\left(250 \mathrm{~m}^{2}\right)$ were required to enable harvest of sufficient amounts of potatoes. This resulted in 36 samples ( 2 years $\times 3$ systems $\times 3$ locations $\times 2$ replicates). To satisfy the nutritional needs of potassium, the potato from organic systems $(\mathrm{OA}, \mathrm{OB})$ also received dry or liquid vinasse (plant-based by-product of sugar and ethanol production) from beetroot (DLG, Copenhagen, Denmark). A lower precipitation in a year 2008 compared to 2007 was balanced by irrigation. The synthetic fertiliser used for potatoes in system C across all locations was a nitrogen-phosphorus-potassium fertiliser (NPK, 14-518). Further details about potato fertilisation and climatic conditions are provided in the supplementary material of Laursen et al. (2011). Samples of cabbage (Brassica oleracea L. convar. capitata (L) Alef. Var. alba DC 'Impala') and carrot (Daucus carota L. 'Bolero') were grown in two successive years 
2007 and 2008 in Aarslev, Denmark as a part of the long-term field trial study VegQure (ThorupKristensen, Dresbøll, \& Kristensen, 2012). At the VegQure location available field space allowed three plot replicates (plot size $125 \mathrm{~m}^{2}$ ). This resulted in 18 individual samples for each vegetable ( 2 years $\times 3$ systems $\times 1$ location $\times 3$ replicates). Synthetic fertiliser was used in the $C$ system of carrot and cabbage (NPK, 21-3-10), while the OA and OB systems relied on use of animal manure or green manures/catch crops, respectively. Irrigation was used in both years but primarily in 2008. Data regarding climate, agricultural management, irrigation, fertilisation and pesticide application are presented in the supplementary information of Mark et al. (2013). All crops were field grown without a cover, thus exposed to the natural climatic conditions. After harvest, potatoes, cabbage and carrots were washed with water and cut into $1 \mathrm{~cm}$ slices/pieces, freeze-dried and stored at $20{ }^{\circ} \mathrm{C}$ in a bag filled with nitrogen gas. The plant material was further processed into a fine flour-like powder by a shaker mill with zirconium-coated grinding jar and ball (MM 400, Retsch GmbH, Haan, Germany) set to $28 \mathrm{~Hz}$ for $1 \mathrm{~min}$. Further details about sample preparation are given in Laursen et al. (2011).

\subsubsection{Potato retail case study}

Various brands of three organic and five conventional potatoes produced in Denmark were randomly selected from supermarkets during autumn 2017 and processed as described in section 2.1.1.

\subsubsection{Fertilisers}

The following samples of fertilisers were collected: three samples of synthetic fertilisers used for conventional potatoes (identical fertilisers were used at all locations), one sample of synthetic 
fertiliser used for conventional carrot and cabbage (identical fertiliser for both crops) and three samples of vinasse used in the organic potato systems. All fertilisers were freeze-dried and $1 \mathrm{~g}$ was homogenized by a zirconium-coated grinding jar and ball (MM 400, Retsch $\mathrm{GmbH}$, Haan, Germany) set to shaking at $28 \mathrm{~Hz}$ for $30 \mathrm{~s}$. The sulphate content and oxygen isotope values of sulphate from these fertilisers were measured as described in section 2.3 and 2.4.

\subsection{Elemental composition of bulk plant tissue}

The content of carbon and nitrogen in the field trial crops was measured with an ANCA-SL elemental analyser coupled to a 20-20 Tracermass mass spectrometer (Sercon Ltd., Crewe, UK). The content of sulphur in the field trial vegetables was measured by inductively coupled plasma-optical emission spectroscopy, ICP-OES (Optima 5300DV, PerkinElmer, Massachusetts, USA). Both analyses were conducted as previously described by Laursen et al. (2011). The elemental composition of carbon and nitrogen of bulk tissue from the retail potato case study were calculated from data obtained during isotope ratio analysis using calibration curves of acetanilide (Sigma Aldrich) for both carbon and nitrogen. The long-term analytical error was determined from the standard deviation of repeatedly measured elemental compositions of the above mentioned standard and was $0.2 \%$ and $0.5 \%$ for carbon and nitrogen, respectively.

\subsection{Anion composition of plant tissue}

Quantification of nitrate and sulphate was done by ion chromatography (Dionex ${ }^{\mathrm{TM}}$ ICS-2100, Thermo Scientific, Sunnyvale, USA) in extracts prepared by mixing of $1.5 \mathrm{~g}$ dried plant powder and $40 \mathrm{~mL}$ of milli-Q water followed by nitrate extraction as described by Laursen et al. (2013). The separation was done on the columns Dionex ${ }^{\mathrm{TM}}$ IonPac ${ }^{\mathrm{TM}}$ AG11-HC $(2 \times 250 \mathrm{~mm})$ and AS11-HC $(4 \times 50 \mathrm{~mm})$ heated 
to $30{ }^{\circ} \mathrm{C}$, injecting $4.8 \mu \mathrm{L}$ of sample, with a flow rate $0.38 \mathrm{~mL} / \mathrm{min}$, using the eluent gradient $30 \mathrm{mM}$ $\mathrm{KOH}$ and with a 15 min runtime. The detection was done in UV and suppressed conductivity mode $(29 \mathrm{~mA})$. Concentrations were quantified by dilutions of Dionex ${ }^{\mathrm{TM}}$ Combined Seven Anion Standard I (\#056933, Thermo Scientific, Sunnyvale, USA). Accuracy and precision were evaluated on repeated analysis of standard solutions and reported values were $>90 \%$ of the true standard concentrations and $<0.1 \mathrm{mg} / \mathrm{L}$, respectively.

\subsection{Stable isotope ratio analysis}

Isotope values were reported using conventional $\delta$-notation according to equation 1 :

$$
\delta^{h} E_{\text {sample } / \text { standard }}=\frac{R_{\text {sample }}-R_{\text {standard }}}{R_{\text {standard }}}
$$

Where $h$ is the heavy isotope of an element $E$ (e.g. ${ }^{18} \mathrm{O},{ }^{15} \mathrm{~N}$, or ${ }^{13} \mathrm{C}$ ) and $R$ represented the corresponding isotope ratio of heavy/light isotopes (e.g. ${ }^{18} \mathrm{O} /{ }^{16} \mathrm{O},{ }^{15} \mathrm{~N} /{ }^{14} \mathrm{~N}$, or ${ }^{13} \mathrm{C} /{ }^{12} \mathrm{C}$ ). The $\delta$-notation isotope values were reported in parts per thousand (\%o) with respect to the international standards $\left(R_{\text {standard }}\right)$ : Vienna-Standard Mean Ocean Water (VSMOW) for $\delta^{18} \mathrm{O}$, AIR for $\delta^{15} \mathrm{~N}$, and Vienna Pee Dee Belemnite (VPDB) for $\delta^{13} \mathrm{C}$.

\subsubsection{Stable isotope ratio analysis of bulk plant tissue}

Stable isotope ratio analyses were conducted in two different laboratories using three different isotope ratio mass spectrometry (IRMS) instruments depending on the elements analysed. Comparability of the isotope data across laboratories was ensured by the use of certified isotope standards. Case study potato isotope analyses $\left(\delta^{13} \mathrm{C}_{\text {bulk }}, \delta^{15} \mathrm{~N}_{\text {bulk }}, \delta^{18} \mathrm{O}_{\text {bulk }}\right)$ were conducted using a PYRO Cube Elemental Analyser (EA) (Elementar, Hanau, Germany) and coupled to an Isoprime100 
mass spectrometer (Elementar, Manchester, UK). Prior to analysis, samples were oven-dried for $4 \mathrm{~h}$ at $60{ }^{\circ} \mathrm{C}$, then $4-5 \mathrm{mg}$ of plant powder was transferred into tin capsules and analysed in combustion mode for $\delta^{13} \mathrm{C}$ and $\delta^{15} \mathrm{~N}$. The PYRO Cube EA combustion tube was set to $1120{ }^{\circ} \mathrm{C}$, reduction tube to $850{ }^{\circ} \mathrm{C}$, oxygen flow to $10 \mathrm{~mL} / \mathrm{min}$ and He flow to $230 \mathrm{~mL} / \mathrm{min}$. Nitrogen and carbon from the samples were simultaneously converted to $\mathrm{N}_{2}$ or $\mathrm{CO}_{2}$ and analysed by the mass spectrometer. Analysis of $\delta^{18} \mathrm{O}_{\text {bulk }}$ was conducted on $0.15-0.2 \mathrm{mg}$ of plant material in silver capsules using PYRO Cube EA pyrolysis settings. The pyrolysis reaction tube was kept at $1450{ }^{\circ} \mathrm{C}$ with a He flow at 100 $\mathrm{mL} / \mathrm{min}$ and He flushing flow of the glassy carbon tube to $90 \mathrm{~mL} / \mathrm{min}$. Oxygen in a sample was converted to CO gas and analysed. Raw isotope data were corrected for drift, linearity, and calibrated to international scales. The drift correction was achieved by including a duplicate of nylon (for $\delta^{15} \mathrm{~N}$ and $\delta^{13} \mathrm{C}$ analysis) or barium sulphate (Sigma Aldrich) (for $\delta^{18} \mathrm{O}$ analysis) every $12^{\text {th }}$ position and calculated as a dependency of sample position on the measured isotope value. Linearity effect correction was done by including six samples of standards in an increasing amount at the beginning and the end of the sequence: acetanilide (Sigma-Aldrich) $\left(0.2-1.2 \mathrm{mg}\right.$ ) for $\delta^{13} \mathrm{C}$ and $\delta^{15} \mathrm{~N}$, and barium sulphate (Sigma-Aldrich) (0.15-0.4 mg) for $\delta^{18} \mathrm{O}$. The linearity correction factor was calculated as a linear function of peak area and measured raw isotopic values. Final calibration was done using isotope standards from the United States Geological Survey (USGS, Virginia, USA) and International Atomic Energy Agency (IAEA, Vienna, Austria). USGS 40 (L-glutamic acid, $\delta^{15} \mathrm{~N}=-4.5 \%$, $\delta^{13} \mathrm{C}=$ $26.389 \%$ ) and USGS 41 (L-glutamic acid, $\delta^{15} \mathrm{~N}=47.6 \%$ o, $\delta^{13} \mathrm{C}=37.626 \%$ o) were used for two-point calibration of $\delta^{15} \mathrm{~N}$ and $\delta^{13} \mathrm{C}$ values. IAEA-601 (benzoic acid, $\delta^{18} \mathrm{O}=23.3 \%$ ), IAEA SO6 (barium sulphate $\delta^{18} \mathrm{O}=-34.1 \%$ ), and NBS-127 (barium sulphate, $\delta^{18} \mathrm{O}=9.3 \%$ ) were used for three-point calibration of $\delta^{18} \mathrm{O}$ values. Replicate analysis of nylon samples for $\delta^{15} \mathrm{~N}$ and $\delta^{13} \mathrm{C}$, or barium sulphate 
(Sigma Aldrich, USA) for $\delta^{18} \mathrm{O}$ were used to calculate long-term precisions as standard deviations and were $<0.2 \% 0,<0.3 \%$ and $<0.5 \%$, for $\delta^{13} \mathrm{C}, \delta^{15} \mathrm{~N}$ and $\delta^{18} \mathrm{O}$, respectively.

Field trial vegetables $\delta^{18} \mathrm{O}_{\text {bulk }}$ analysis was conducted using $0.5 \mathrm{mg}$ of plant powder in silver capsules and introduced to a PYRO Cube EA (Elementar, Hanau, Germany) coupled to an Isoprime VisION IRMS (Isoprime, Manchester, UK). The raw data were corrected as described above. Precision and accuracy were evaluated by including an internal standard (nylon) and international certified reference materials: IAEA 600 (caffeine, $\delta^{18} \mathrm{O}=-3.5 \%$ ) and USGS-35 (sodium nitrate, $\delta^{18} \mathrm{O}=57.5 \%$ ). Precision was measured as a standard deviation of $\delta^{18} \mathrm{O}$ for the nylon samples and was $<0.4 \%$.

Field trial vegetables $\delta^{13} \mathrm{C}_{\text {bulk }}$ and $\delta^{15} \mathrm{~N}_{\text {bulk }}$ analysis was conducted on a Europa Scientific ANCA-SL Elemental Analyser coupled to a Europa Scientific 20-20 Tracermass mass spectrometer (Sercon Ltd., Crewe, UK) using $4 \mathrm{mg}$ of plant powder in tin capsules as detailed by Laursen et al. (2013).

\subsubsection{Stable isotope ratio analysis of oxygen and nitrogen in plant-derived nitrate}

The nitrate isotopes $\left(\delta^{15} \mathrm{~N}_{\text {nitrate }}\right.$ and $\left.\delta^{18} \mathrm{O}_{\text {nitrate }}\right)$ in the field-grown potato, carrot and cabbage were analysed using the bacterial denitrification assay (Casciotti et al., 2002; Sigman et al., 2001). The procedure for plant material preparations were previously described by Laursen et al. (2013) and included: nitrate extraction from the plant tissue, nitrate quantification by ion chromatography, preparation of denitrifier cultures, bacterial conversion of sample nitrate into nitrous oxide, and stable isotope ratio analysis of nitrous oxide. The isotopes were measured on a ThermoFinnigan GasBench and a PreCon trace gas concentration system interfaced to a ThermoScientific Delta V Plus isotope-ratio mass spectrometer (Bremen, Germany). The calibration standards were the 
nitrates USGS 32, USGS 34, and USGS 35, supplied by NIST (National Institute of Standards and Technology, Gaithersburg, MD). Long-term precision was $0.2 \%$ for $\delta^{15} \mathrm{~N}$ and $0.3 \%$ for $\delta^{18} \mathrm{O}$.

2.4.3 Extraction and stable isotope ratio analysis of oxygen in plant-derived sulphate A protocol for sulphate extraction from plant tissue for isotope ratio analysis $\left(\delta^{18} \mathrm{O}_{\text {sulphate }}\right)$ was developed using a combination of several protocols for isotopic analysis of sulphate from sea- and freshwater (Blake, Surkov, Böttcher, Ferdelman, \& Jørgensen, 2006; Fischer \& Rhinehammer, 1953; Kang, Mayer, \& Mitchell, 2012; Tanz \& Schmidt, 2010). Overall, the basic principle was extraction of dissolved plant sulphate in water and precipitation as $\mathrm{BaSO}_{4}$ by addition of a $\mathrm{BaCl}_{2}$ solution. In more details, $5 \pm 0.1 \mathrm{~g}$ of freeze-dried powdered plant material (or $5 \pm 0.1 \mathrm{~g}$ of dry vinasse, or $0.5 \pm 0.1 \mathrm{~g}$ of powdered synthetic fertiliser) was added to $40 \mathrm{~mL}$ of milli-Q water, well-mixed by vortexing $(2 \times 30 \mathrm{~s})$ and incubated for $30 \mathrm{~min}$ at room temperature. The sludge was then acidified to $\mathrm{pH} 1.5$ using $6 \mathrm{M} \mathrm{HCl}$ to prevent co-precipitation of $\mathrm{BaCO}_{3}$ (Kang et al., 2012). Residual plant tissue was removed by centrifugation ( $20 \mathrm{~min}, 13400 \mathrm{~g}$ at a room temperature) and the supernatant was collected and filtered in two steps. First, through a grade 4 cellulose filter paper, diameter $4.25 \mathrm{~cm}$, pore size $20-25 \mu \mathrm{m}$ (Whatman plc, Maidstone, UK) to remove residual plant material, and then through a Minisart ${ }^{\circledR} 0.45 \mu \mathrm{m}$ surfactant-free cellulose acetate syringe filter (Sartorius AG, Göttingen, Germany) attached to a $25 \mathrm{~mL}$ plastic syringe to remove fine particles. For the fertilisers, $1 \mathrm{~mL}$ of the filtered sulphate extract was analysed for sulphate content by ion chromatography as described in section 2.3. The filtered extracts were cooled to $4{ }^{\circ} \mathrm{C}$ to avoid unspecific binding of Ba. Then $2.5 \mathrm{~mL}$ of $0.5 \mathrm{M} \mathrm{BaCl}_{2}$ (Sigma Aldrich, USA) prepared a day in advance and cooled to $4{ }^{\circ} \mathrm{C}$ was added into the cooled and filtered plant extracts. The solution was vortexed for $30 \mathrm{~s}$ and placed at $4{ }^{\circ} \mathrm{C}$ for $12 \mathrm{~h}$. 
During the incubation, a change in colour from transparent to milky white could be observed as a results of $\mathrm{BaSO}_{4}$ precipitation.

The $\mathrm{BaSO}_{4}$ was collected by centrifugation (20 min, $13400 \mathrm{~g}$ at $4{ }^{\circ} \mathrm{C}$ ). Subsequently, the $\mathrm{BaSO}_{4}$ pellet was washed with $0.5 \mathrm{~mL}$ of $6 \mathrm{M} \mathrm{HCl}$ by pipetting to make a blend. The blend was transferred to a new tube, vortexed for $30 \mathrm{~s}$ and centrifuged (10000 g, $15 \mathrm{~min}$, at room temperature). The supernatant was discarded and the pellet washed twice with $1 \mathrm{~mL}$ of milli-Q water. Remaining moisture was removed from the precipitate by freeze-drying until complete dryness.

Oxygen isotope analysis of plant-derived sulphate was conducted as detailed in section 2.4.1. For field trial vegetables, $0.6-0.7 \mathrm{mg}$ of dried $\mathrm{BaSO}_{4}$ was measured in silver capsules using the PyroCube EA in pyrolysis mode (Elementar, Hanau, Germany) coupled to an Isoprime VisION IRMS (Elementar, Manchester, UK). For retail potatoes, $0.2-0.3 \mathrm{mg}$ of dried $\mathrm{BaSO}_{4}$ was loaded to silver capsules and analysed by an elementar PyroCube EA in pyrolysis mode (Elementar, Hanau, Germany) coupled to an Isoprime100 IRMS (Elementar, Manchester, UK).

The developed sulphate extraction method was optimized regarding extraction efficiency and sulphate purity by evaluating the isotopic fractionation at each optimization step. A heating of the extract $\left(0.5 \mathrm{~h}\right.$ at $\left.95^{\circ} \mathrm{C}\right)$ was tested during the method development in order to increase the extraction efficiency and accelerate the removal of carbonate in the form $\mathrm{CO}_{2}$. However, the heating step did not increase the sulphate yield nor affect the isotope values of the precipitated barium sulphate. The heating step was therefore excluded to increase the sample throughput. A contamination of $\mathrm{BaSO}_{4}$ by dissolved organic matter during precipitation could potentially cause shifts from the true $\delta^{18} \mathrm{O}_{\text {sulphate }}$ values (Kang et al., 2012). The level of contamination was therefore addressed by analysing the carbon content of extracted $\mathrm{BaSO}_{4}$ in randomly selected plant samples as described in section 2.2. 
Oxygen isotope fractionation during sulphate extraction and precipitation was evaluated using $\mathrm{K}_{2} \mathrm{SO}_{4}$ with a known $\delta^{18} \mathrm{O}$ bulk value and selected plant samples. The potential isotope exchange with water was investigated using isotopically distinct waters $\left(\delta^{18} \mathrm{O}=-9.0 \%\right.$ ond $8.4 \%$ ). The enriched water was prepared by heating Milli-Q water $\left(\delta^{18} \mathrm{O}=-9.0 \%\right.$ o $)$ in a water bath set at $70{ }^{\circ} \mathrm{C}$ during daytime $(8 \mathrm{~h})$ and $40{ }^{\circ} \mathrm{C}$ at nights $(16 \mathrm{~h})$ for seven days. The enriched water was stored at $5{ }^{\circ} \mathrm{C}$ until use. The isotopic differences in the precipitated sulphate from either $\mathrm{K}_{2} \mathrm{SO}_{4}$ or plants using the two water sources were $\leq 0.4 \%$ and were not statistically significant.

\subsubsection{Stable isotope analysis of water}

The $\delta^{18} \mathrm{O}$ of water used during the sulphate method development was analysed using the $\mathrm{CO}_{2}$ equilibration technique by a headspace autosampler (Multiflow Bio, Isoprime Ltd, UK) coupled to an Isoprime100 IRMS (Elementar, Manchester, UK). Samples of $200 \mu \mathrm{l}$ water were pipetted into glass vials (Exetainer ${ }^{\circledast} 3.7 \mathrm{~mL}$ - round bottom, Labco Limited, Lampeter, UK), heated to $40{ }^{\circ} \mathrm{C}$ and flushed with a gas mixture containing $95 \% \mathrm{He}$ and $5 \% \mathrm{CO}_{2}$ for $200 \mathrm{~s}$. The gas was left to equilibrate with water for $5 \mathrm{~h}$, and the isotope ratio of $\mathrm{CO}_{2}$ was then analysed. All samples were analysed as triplicates and the $\delta^{18} \mathrm{O}$ values were calibrated using International Atomic Energy Agency (IAEA, Vienna, Austria) standards: Vienna-Standard Mean Ocean Water 2 (VSMOW2) and Standard Light Antarctic Precipitation 2 (SLAP2). The long-term $\delta^{18} \mathrm{O}$ precision was expressed as the standard deviation of repeatedly analysed intra-laboratory water standards and was $<0.2 \%$.

\subsection{Statistical analysis}

Univariate statistical analyses were conducted in RStudio software version 1.1.383 (Boston, USA). Data was checked for variance homogeneity and Gaussian distribution. In all figures and tables, the 
isotope data for each vegetable was analysed using one-way ANOVA. Group-wise comparisons were done by post-hoc Tukey's honest significant difference test. The results were considered statistically significant at $p<0.05$ level. In addition, the interactions between year and growth systems for fieldgrown carrot and cabbage were analysed by two-way ANOVA. The isotope data of field-grown potato were analysed by three-way ANOVA looking for interactions between years, growth system, and geographical location.

The isotope parameters $\delta^{15} \mathrm{~N}_{\text {bulk }}$ and $\delta^{18} \mathrm{O}_{\text {sulphate }}$ were used to classify the retail potatoes as organic or conventional utilizing the data from well characterized field-grown potato in a quadratic discriminant analysis (QDA). The field potato data set (36 samples) was divided into two equal groups (based on year of production) to be used as learning model set (model training) and validation set (model testing). The field potato learning data set was categorically classified based on the three fertilisation systems ( $C, O A$ and $O B)$. The accuracy of the model was then evaluated by the validation set by looking for misclassification between $C$ and $O A$ or $O B$ systems, thus misclassifications between $\mathrm{OA}$ and $\mathrm{OB}$ groups were not considered as all crops within these systems were grown according to the organic regulations. Finally, the model was applied to predict and assign the fertilisation strategy (organic or conventional) to the retail potatoes test set. The total probability for the organic system was calculated as a sum of probabilities for OA and OB systems. The quadratic discriminant analysis model was performed in $\mathrm{JMP}^{\circledR} 13$ software (SAS Institute, Cary, USA). 


\section{Results and Discussion}

\subsection{Field study}

\subsubsection{Elements and inorganic anions in bulk plant tissue}

The elemental (carbon, nitrogen and sulphur) and anion (sulphate, nitrate) contents did not reveal any systematic or statistical significant differences between the two organic systems relying on use of animal manures $(\mathrm{OA})$ or legume-based green manures $(\mathrm{OB})$ versus the conventional $(\mathrm{C})$ system (Table 1). These parameters were therefore not considered suitable for organic authentication. Higher nitrogen contents were previously reported for conventional crops versus organic produce in a systematic review (Dangour, Dodhia, Hayter, Allen, Lock, \& Uauy, 2009). However, in another study on cereals and vegetables, there were no systematic differences in nitrogen content between conventional and the organic treatments (Laursen et al., 2011), which corresponds to our findings (Table 1). Similarly, no systematic differences were found for the nitrate content of organic and conventional crops. Nitrate constituted $<1 \%$ of the total nitrogen content in potato and carrot, while in cabbage the average nitrate contribution was $3 \%$ of the total nitrogen. The nitrate contents (Table 1) were approximately $5 \times$ lower than ranges previously documented in the literature for potato, cabbage and carrot (Tamme, Reinik, \& Roasto, 2010). Variation in nitrate contents of crops can be explained by a number of factors including the fertilisation rate, nitrate leaching, efficiency of nitrogen assimilation, plant species and genotype, plant maturity and storage time (Tamme et al., 2010). However, nitrate contents were in all cases sufficiently high to enable compound-specific isotope ratio analysis (section 2.4.2).

The sulphur content of cabbage was higher compared to potato and carrot, which is a characteristic trait of the Brassica genus (Reuter \& Robinson, 1997). The total sulphate tissue contents (Table 1) were similar to values reported in literature (Florin, Neale, Goretski, \& Cummings, 1993). According 
to Blake-Kalff et al. (1998), oilseed rape (Brassica napus L.) leaves accumulated $42 \%$ to $90 \%$ of sulphur as sulphate from youngest to oldest leaves, respectively. Moreover, sulphur deficiency conditions caused a decrease of the relative sulphate content in the young and middle leaves. Potato tubers from the field trial contained on average $56 \pm 7 \%(n=36, \pm$ SD) of sulphur as sulphate, carrot roots $33 \pm 8 \%(n=18, \pm S D)$ and cabbage heads $26 \pm 4 \%(n=18, \pm S D)$. The decreasing relative sulphate contribution of the plant sulphur pool could be an indication of increased sulphate requirement and assimilation for different plant species - with cabbages having the highest requirement. Nevertheless, since the organic treatments $O A$ and $O B$ did not manifest in lower sulphur and sulphate contents compared to conventional produce (Table 1), we conclude that mineralization of the organically-bound sulphur into plant-available sulphate had occurred - an essential prerequisite for the successful evaluation of $\delta^{18} \mathrm{O}_{\text {sulphate }}$ as a novel marker for organic authentication.

\subsubsection{Bulk tissue isotopic composition}

Stable isotope ratio analysis of carbon $\left(\delta^{13} \mathrm{C}_{\text {bulk }}\right)$ and oxygen $\left(\delta^{18} \mathrm{O}_{\text {bulk }}\right)$ in bulk tissue of vegetables did not reveal any differences between the growth systems $\mathrm{C}, \mathrm{OA}$ and $\mathrm{OB}$ (Table 1). The vegetable $\delta^{13} C_{\text {bulk }}$ values (Table 1 ) were comparable to values previously reported for a range of field-grown vegetables (Schmidt et al., 2005). Plant $\delta^{18} \mathrm{O}_{\text {bulk }}$ is strongly affected by the $\delta^{18} \mathrm{O}$ of soil water and subsequent evaporative enrichment during transpiration (Barbour, 2007). However, there was no effect of the agricultural production system on $\delta^{18} \mathrm{O}_{\text {bulk }}$ values. A spatial variability in $\delta^{18} \mathrm{O}$ of rain water often makes $\delta^{18} \mathrm{O}_{\text {bulk }}$ a suitable marker for determining the geographical origin of food products (Laursen et al., 2016). The observed $\delta^{18} \mathrm{O}_{\text {bulk }}$ values in the studied vegetables were 
comparable to wheat grown in Denmark (Laursen et al., 2013) and there was an effect of geographical location on $\delta^{18} \mathrm{O}_{\text {bulk }}$ values of potatoes (Supplementary material Table S2).

Average $\delta^{15} \mathrm{~N}_{\text {bulk }}$ values for the OA system across vegetables were $4.5,7.5$ and $5.2 \%$ for potato, cabbage and carrot, respectively and were statistically higher when compared to the $\mathrm{C}$ and $\mathrm{OB}$ systems (Table 1). Similarly, Laursen et al. (2013) found that animal manure fertilisation caused statistically higher $\delta^{15} \mathrm{~N}_{\text {bulk }}$ in wheat when compared to conventional or legume-based green manure fertilisation. Bateman and Kelly (2007) demonstrated a difference between organic manures such as compost and animal manures with an average $\delta^{15} \mathrm{~N}$ value at $8.1 \%$ and synthetic fertilisers averaging at $-0.2 \%$. The $\delta^{15} \mathrm{~N}$ signatures of synthetic fertilisers and nitrogen-fixing plants close to $0 \%$ is caused by the atmospheric origin of nitrogen $\left(\delta^{15} \mathrm{~N}_{\text {Air }}=0 \%\right.$, while volatilization of nitrogen as ammonia is one of the main processes causing enrichment of animal manure fertilisers in system OA (Bateman and Kelly, 2007; Choi et al., 2017; Vitòria et al., 2004). Despite these limitations, a $\delta^{15} \mathrm{~N}_{\text {bulk }}$ threshold value for organic potato has been proposed at $4.3 \%$ (Camin et al., 2007). In the field trial, $100 \%$ of $C$ and $O B$ potatoes fell below this threshold while $67 \%$ of OA potatoes were above. In organic agricultural practices, the nitrogen input often relies on the use of animal manure or compost, while green manure application alone is less common. Taking this into consideration,

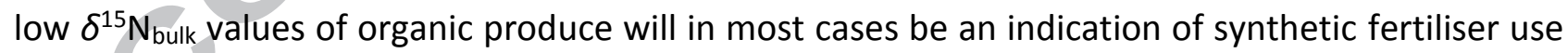
and thereby potential fraud, but complementary analyses such as pesticide residue analysis is strongly recommended. An alternative approach that specifically addresses potential illegal fertilisation practices is compound-specific isotope ratio analysis (Laursen et al., 2013).

\subsubsection{Compound-specific stable isotope ratio analysis}

\subsubsection{Nitrate isotope analysis}


The presented data suggests that nitrate isotope analysis has limited applicability for organic authentication across different plant species and plant organs. Stable isotope ratio analysis of oxygen in nitrate $\left(\delta^{18} \mathrm{O}_{\text {nitrate }}\right)$ from potatoes revealed average values for the $\mathrm{C}$ system at $23.4 \%$ and was statistically higher in comparison to the potatoes from the two organic production systems OA and OB with 18.1 and $17.9 \%$, respectively (Fig. 1A). Mihailova et al. (2014) found similar $\delta^{18} \mathrm{O}_{\text {nitrate }}$ values in retail potatoes, where the majority of organic potatoes had values lower than $20 \%$, while most of conventional samples were above $20 \%$. Moreover, Mihailova et al. (2014) also observed more than $15 \%$ higher $\delta^{18} \mathrm{O}_{\text {nitrate }}$ values in tomato when compared to potato. Cabbage and carrot from the $C, O A$ and $O B$ treatments showed no statistical differences between the average $\delta^{18} \mathrm{O}_{\text {nitrate }}$ values (Fig. 1A). Stable isotope analysis of nitrogen in nitrate $\left(\delta^{15} \mathrm{~N}_{\text {nitrate }}\right)$ showed statistical differences in carrots and potatoes between C and OA systems, but no differences were found when $\mathrm{OB}$ was compared to the $\mathrm{C}$ or $\mathrm{OA}$ treatments. For cabbage, there were no statistical differences in $\delta^{15} \mathrm{~N}_{\text {nitrate }}$ values between the production systems (Table 1).

The nitrogen and oxygen in synthetic nitrate fertilisers originates from the atmosphere, which has $\delta^{15} \mathrm{~N}$ values $=0 \%$ and $\delta^{18} \mathrm{O}=23.5 \%$ (Junk \& Svec, 1958; Kroopnick \& Craig, 1972). This leads to synthetic fertilisers with $\delta^{15} \mathrm{~N}_{\text {nitrate }}$ values close to $0 \%$ ond $\delta^{18} \mathrm{O}_{\text {nitrate }}$ values ranging from 17 to $25 \%$ (Vitòria et al., 2004; Xue et al., 2009). In the organic systems, the nitrate isotopic signature was expected to be a result of mineralization and nitrification of organically bound nitrogen, yielding a typical range of soil $\delta^{15} \mathrm{~N}_{\text {nitrate }}$ values from 0 to $8 \%$ o. For soil $\delta^{18} \mathrm{O}_{\text {nitrate, }}$ Xue et al. (2009) summarized that two oxygen atoms in the soil-derived nitrate come from soil water and one from soil air resulting in $\delta^{18} \mathrm{O}_{\text {nitrate }}$ values ranging from -10 to $10 \%$ depending on the $\delta^{18} \mathrm{O}$ of the soil water. However, additional processes can cause higher values than the theoretical soil $\delta^{18} \mathrm{O}_{\text {nitrate }}$ due to isotopic enrichment processes such as evaporative enrichment of soil water or respiratory 
enrichment of soil air oxygen (Xue et al., 2009). The relatively higher enrichments of $\delta^{18} \mathrm{O}_{\text {nitrate }}$ and $\delta^{15} \mathrm{~N}_{\text {nitrate }}$ in vegetables, when compared to the theoretical isotopic values of the source, may be explained by isotopic fractionation during assimilation of nitrate into organic compounds (Mariotti, Mariotti, Champigny, Amarger, \& Moyse, 1982). Analogically, Mihailova et al. (2014) observed enrichments as large as $20 \%$ for both $\delta^{18} \mathrm{O}_{\text {nitrate }}$ and $\delta^{15} \mathrm{~N}_{\text {nitrate }}$ in lettuce leaves when compared to the source nitrate. This highlights one of the challenges associated with using nitrate isotope analysis for organic authentication across different plant species and organs. In addition, the denitrifier method is costly and time-consuming and no other suitable method for nitrate isotope analysis is currently available. The practical applicability of nitrate isotope analysis for authenticity testing of organic vegetables is thus considered limited.

\subsubsection{Sulphate isotope analysis}

The use of sulphate oxygen isotope ratio analysis for discriminating organic and conventional vegetables was successful for all 3 plant species with conventional crops showing statistically significant higher values (Fig. 1B). This enabled establishment of thresholds values for classification of organically produced potato, cabbage and carrot. The thresholds were calculated as a grand mean of two numbers: i) average $\delta^{18} \mathrm{O}_{\text {sulphate }}$ values for system $\mathrm{C}-1$ standard deviation; ii) average $\delta^{18} \mathrm{O}_{\text {sulphate }}$ value for both organic systems +1 standard deviation. Consequently, the threshold value for $\delta^{18} \mathrm{O}_{\text {sulphate }}$ in potato was set at $5.1 \%$. Organic potatoes from the organic systems fell below this proposed threshold value in $92 \%$ of cases, while $83 \%$ of the conventional potatoes were above $5.1 \%$. The $\mathrm{OA}$ and $\mathrm{OB}$ potato $\delta^{18} \mathrm{O}_{\text {sulphate }}$ values were approximately $2 \%$ higher than $\mathrm{OA}$ and $\mathrm{OB}$ carrot and cabbage (Fig. 1B). The isotope signature of conventional potatoes was influenced by the synthetic fertiliser, which contained $15.2 \%$ of sulphate with a $\delta^{18} \mathrm{O}_{\text {sulphate }}$ value at $14.0 \%$ (Table 2 ). 
The organic potatoes were also fertilised with vinasse, which contained $3.3 \%$ of water-soluble sulphate with a $\delta^{18} \mathrm{O}$ value of $10.1 \%$ (Table 2). Mixing of sulphate from vinasse and sulphate from mineralized organic matter could potentially explain the higher $\delta^{18} \mathrm{O}_{\text {sulphate }}$ values of organic potatoes compared to carrot or cabbage (Fig. 1 B).

Cabbage showed the largest difference between the conventional system $\mathrm{C}$ and the organic systems $\mathrm{OA}$ and $\mathrm{OB}$. The $\delta^{18} \mathrm{O}_{\text {sulphate }}$ threshold value for cabbage was set at $3.6 \%$ and enabled $100 \%$ correct classification of samples. The synthetic fertiliser used to fertilise the conventional cabbage and carrot contained $14.4 \%$ sulphate with a $\delta^{18} \mathrm{O}$ value at $16.2 \%$ (Table 2 ). The more prominent difference between organic and conventional cabbage could be caused by higher fertiliser application rates compared to potato and carrot (Thorup-Kristensen et al., 2012).

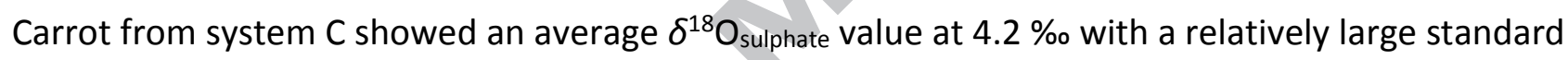
error of $0.8 \%$ (Fig. 1B), which was caused by $3 \%$ o variation between the production years. There was no statistical difference between the $C$ system carrot and OA system and between the OA system and OB. However, carrot system C and OB were statistically different. Nevertheless, a $\delta^{18} \mathrm{O}_{\text {sulphate }}$ threshold was still proposed at $3 \%$. However, only $50 \%$ of $\mathrm{C}$ carrots were classified correctly by using the threshold value. In contrast, organic samples were classified correctly in $92 \%$ of cases.

The sulphate in soil can originate directly from the fertiliser or as a result of sulphur mineralization processes (Mayer et al., 1995; Vitòria et al., 2004). The sulphate in synthetic fertilisers arises from the main ingredient in the manufacturing - sulphuric acid, which has been shown to have a $\delta^{18} \mathrm{O}_{\text {sulphate }}$ value at $12.9 \%$ (Vitòria et al., 2004). The sulphate formed via mineralization of organically-bound sulphur contains $60-70 \%$ of the oxygen from soil water (with generally negative $\left.\delta^{18} \mathrm{O}\right)$ with the rest being derived from the atmosphere $\left(\delta^{18} \mathrm{O}=23.5 \%\right.$ ). This is resulting in soil 
sulphate with $\delta^{18} \mathrm{O}$ values in the range 0-8 \%o (Kroopnick \& Craig, 1972; Mayer et al., 1995; Vitòria et al., 2004). Under sulphur surplus conditions a large proportion of sulphur taken up by plants is not assimilated, but is stored in vacuoles as sulphate and re-mobilized and assimilated when needed (Blake-Kalff, Harrison, Hawkesford, Zhao, \& McGrath, 1998; Hawkesford \& De Kok, 2006). Therefore, based on the sulphur and sulphate content (Table 1), the sulphate extracted by the present method likely reflects the plant vacuolar sulphate pool. Very little is known about the isotopic fractionations connected with the metabolic processes controlling the $\delta^{18} \mathrm{O}_{\text {sulphate }}$ signatures of plants. Based on studies describing ${ }^{34} \mathrm{~S}$ isotope fractionation in plant metabolism, sulphate uptake and assimilation are likely to be associated with ${ }^{18} \mathrm{O}_{\text {sulphate }}$ isotopic fractionations (Tcherkez \& Tea, 2013). This could explain that plant $\delta^{18} \mathrm{O}_{\text {sulphate }}$ did not completely reflect the fertiliser values.

\subsection{Retail potato case study}

The suitability of $\delta^{18} \mathrm{O}_{\text {sulphate }}$ as a marker for organic authentication was tested in a case study using retail conventional and organic potatoes from different locations in Denmark. In addition, the elemental, bulk isotope and anion composition was analysed (supporting information Table S4). The case study demonstrated that the limitations of $\delta^{15} \mathrm{~N}_{\text {bulk }}$ for organic authentication could be eliminated by classification using $\delta^{18} \mathrm{O}_{\text {sulphate }}$ values.

The conventional retail potatoes $A, B, C, D$ and $E$ had $\delta^{15} \mathrm{~N}_{\text {bulk }}$ values lower than $2.5 \%$ o (Fig. 2.A). The organic potato $\mathrm{F}$ and I showed $\delta^{15} \mathrm{~N}_{\text {bulk }}$ values above $3.9 \%$, while the organic potatoes $\mathrm{G}$ and $\mathrm{H}$ had $\delta^{15} \mathrm{~N}_{\text {bulk }}$ values below $2 \%$, and were therefore similar to the conventional retail potatoes. The conventional potatoes $B, C, D$ and $E$ had $\delta^{18} \mathrm{O}_{\text {sulphate }}$ values above $5.3 \%$ (Fig. 2B), while the conventional potato $\mathrm{A}$ deviated from the rest of conventional potatoes and had a $\delta^{18} \mathrm{O}_{\text {sulphate }}$ value 
at $3.0 \%$ (Fig. 2.B). The organic retail potatoes F, G and I fell between 2.2 and $-1.0 \%$ (Fig. 2B). The organic retail potato $\mathrm{H}$ had the highest $\delta^{18} \mathrm{O}_{\text {sulphate }}$ value of all organic potatoes at $5.3 \%$ (Fig. 2B). Authenticity testing based on the threshold $\delta^{15} \mathrm{~N}_{\text {bulk }}$ value $4.3 \%$ as proposed by Camin et al. (2007) classified only one out of four organic potatoes as authentic (potato F) and the rest was classified as conventional (Table 3). Laursen et al. (2013) demonstrated $\delta^{15} \mathrm{~N}_{\text {bulk }}$ as a powerful marker of animal manure fertilisation, however, it was biased by the use of legume-based manures. This could also have led to the false negatives in this retail case study. The threshold value for $\delta^{18} \mathrm{O}_{\text {sulphate }}$ was set at $5.1 \%$ based on the field study. Classification by $\delta^{18} \mathrm{O}_{\text {sulphate }}$ revealed two differences from the package label: conventional retail potato $\mathrm{A}$ was classified as organic and organic retail potato $\mathrm{H}$ as conventional (Table 3). However, it should be mentioned that classifications based on threshold values could be biased by overlapping values and the conclusions should therefore be used only as an indication of potential fraud or mistakes.

The $\delta^{15} \mathrm{~N}_{\text {bulk }}$ and $\delta^{18} \mathrm{O}_{\text {sulphate }}$ values were combined for organic authenticity testing using a quadratic discriminant analysis (QDA) model based on field trial data (Table 3). A validation set revealed $88 \%$ classification accuracy of the model - two conventional samples were misclassified as organic out of total 18 samples. The QDA showed deviations from the labelling claims for several samples in the case study. Conventional potato A belonged with $100 \%$ probability to the organic system, conventional potato $\mathrm{C}$ was likely produced as organic with $91 \%$ chance, and organic potato $\mathrm{H}$ was with $43 \%$ chance conventional or $57 \%$ organic (Table 3). The combined use of $\delta^{15} \mathrm{~N}_{\text {bulk }}$ and $\delta^{18} \mathrm{O}_{\text {sulphate }}$ indicated potential use of synthetic fertiliser for potato $\mathrm{H}$. However, it should be noted that high $\delta^{18} \mathrm{O}_{\text {sulphate }}$ values could also be caused by the use of potassium sulphate, which is allowed as a $\mathrm{K}$ and $\mathrm{S}$ source in organic farming and has reported $\delta^{18} \mathrm{O}_{\text {sulphate }}$ value of $13.5 \%$ (Vitòria et al., 2004). In this specific case, further analyses such as pesticide residue analyses could confirm if 
organic regulations were violated. The summary of the QDA results is shown in supplementary material Table S3. The QDA results illustrated the advantage of authenticity testing based on $\delta^{15} \mathrm{~N}_{\text {bulk }}$ and $\delta^{18} \mathrm{O}_{\text {sulphate }}$ isotope markers in combination with a well-characterized reference data set.

\subsection{Stable isotope ratio analysis for organic authentication}

To our knowledge, this is the first study utilizing $\delta^{18} \mathrm{O}_{\text {sulphate }}$ for authenticity testing of organic plant products. It was documented that organic authentication using sulphate isotope ratio analysis is feasible across a variety of plant species and organic fertilisation strategies. Of the analysed markers, $\delta^{18} \mathrm{O}_{\text {sulphate }}$ was by far the most promising for organic authenticity testing. However, several advantages and limitations are associated with each of the isotope markers investigated in this study $\left(\delta^{15} \mathrm{~N}_{\text {bulk }}, \delta^{18} \mathrm{O}_{\text {nitrate, }} \delta^{18} \mathrm{O}_{\text {sulphate }}\right)$ regarding their applicability for organic authenticity testing. From an analytical perspective, analysis of $\delta^{15} \mathrm{~N}_{\text {bulk }}$ requires the least amount of time and plant material only drying, homogenization and approximately $4 \mathrm{mg}$ of tissue for analysis, thus data be obtained within days. Nitrate-based analysis requires specialized hardware and up to 6 weeks to complete especially if the denitrifier method is not used on a frequent and routine basis. However, it is a highly sensitive method with a requirement for only $20 \mathrm{nmol}$ of nitrate (Laursen et al., 2013). For example, a plant with a hypothetical low nitrate content of $100 \mathrm{mg} \mathrm{kg}^{-1} \mathrm{DW}$ (e.g. tomato) would contain $20 \mathrm{nmol}$ of nitrate in approximately $12 \mathrm{mg}$ of dry tissue (Tamme et al., 2010). Preparation and analysis of $\delta^{18} \mathrm{O}_{\text {sulphate }}$ can be conducted in just a few days; however, the method requires a larger sample amount compared to nitrate isotope analysis. To obtain $1 \mathrm{mg}$ of $\mathrm{BaSO}_{4}$ precipitate from a plant with a sulphate content of e.g. $2 \mathrm{mg} \mathrm{g}^{-1} \mathrm{DW}$, roughly $5 \mathrm{~g}$ of dry material is necessary. This may also represents an analytical challenge for plant species and plant organs with inherently low sulphate contents such as cereal grains (Florin et al., 1993; Hawkesford \& De Kok, 2006). 
Analysis of sulphate showed carbon contamination $<5 \%$ for potato and cabbage and $<13 \%$ for carrot precipitates. If the carbon contamination originated from plant organic matter containing for example $45 \%$ of oxygen with $\delta^{18} \mathrm{O}_{\text {bulk }}$ values at $25 \%$, the $\delta^{18} \mathrm{O}_{\text {sulphate }}$ value would be significantly higher in carrot compared to cabbage or potato. However, this was not observed (Figure 1B). This suggests that the contamination of the precipitated sulphate was not caused by oxygen-rich plant tissue residues, but possibly rather carbon-rich organic matter (i.e. carotenoids). The potential carbon contamination was accepted as the $\delta^{18} \mathrm{O}_{\text {sulphate }}$ discriminative power was not compromised and the low sample preparation time was considered more important than sulphate purity. However, in future experiments, the purity could be improved e.g. by precipitate ashing (Blake et al., 2006), or by a hydrogen peroxide treatment to remove residual organic matter.

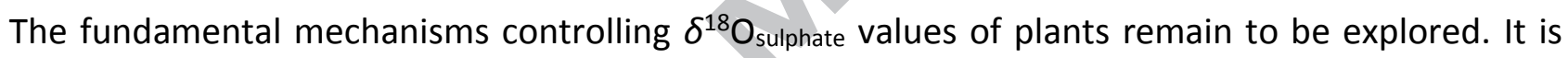
assumed that the low $\delta^{18} \mathrm{O}_{\text {sulphate }}$ values of organically grown plants are caused by mineralization and are thus affected by the $\delta^{18} \mathrm{O}$ values of soil water (Mayer et al., 1995). The global distribution of $\delta^{18} \mathrm{O}$ rain patterns suggests that our proposed threshold organic $\delta^{18} \mathrm{O}_{\text {sulphate }}$ values should theoretically apply to temperate climate zones (Bowen \& Wilkinson, 2002). However, in the tropical regions $\delta^{18} \mathrm{O}$ values of precipitation are up to $10 \%$ higher than in Europe. This could potentially cause $\delta^{18} \mathrm{O}_{\text {sulphate }}$ of organic vegetables from such climates to be closer to the $\delta^{18} \mathrm{O}_{\text {sulphate }}$ of conventional produce. A few studies have used a dual isotope approach including both sulphur and oxygen isotope analysis of sulphate to track various environmental sources of sulphate (Vitòria et al., 2004). However, there is a documented overlap between $\delta^{34} S_{\text {sulphate }}$ of synthetic fertilisers and soil sulphate (Vitòria et al., 2004). Thus, $\delta^{34} S_{\text {sulphate }}$ analysis is not considered suitable for authenticity testing of organic vegetables. 


\section{Conclusions}

A method for oxygen isotope ratio analysis of plant-derived sulphate was developed and applied to discriminate field-grown organic and conventional potatoes, cabbages and carrots while comparing the classification power with existing isotope markers for organic authentication. It was concluded that oxygen isotope analysis of sulphate is a promising novel method for authentication of organic vegetables with superior classification power compared to traditional isotope markers including bulk tissue nitrogen. The $\delta^{18} \mathrm{O}_{\text {sulphate }}$ values could be linked to the fertilisation strategy of organic and conventional production and lower $\delta^{18} \mathrm{O}_{\text {sulphate }}$ values were consistently found for organic vegetables compared to conventional produce. A similar pattern was seen for $\delta^{18} \mathrm{O}_{\text {nitrate, }}$ but this parameter did only succeed in discriminating organic and conventional potatoes and not cabbages and carrots.

A case study using organic and conventional retail potatoes demonstrated the complementarity of $\delta^{18} \mathrm{O}_{\text {sulphate }}$ and $\delta^{15} \mathrm{~N}_{\text {bulk }}$ analysis for organic authentication. A classification based on $\delta^{18} \mathrm{O}_{\text {sulphate }}$ or $\delta^{15} \mathrm{~N}_{\text {bulk }}$ threshold values revealed several deviations from the labelling claim. This was confirmed by quadratic discriminant analysis when a model based on both $\delta^{18} \mathrm{O}_{\text {sulphate }}$ and $\delta^{15} \mathrm{~N}_{\text {bulk }}$ values from field trial potatoes was build and used to categorize and authenticate the retail potatoes.

For an improved mechanistic understanding of the obtained results, key factors controlling the isotopic signature of sulphate in soils and plants should be further investigated. Particularly, the mechanisms involved in soil sulphur mineralization, plant sulphate uptake and plant sulphur metabolism and the potentially associated sulphate oxygen isotope fractionations. The developed method was not biased by geographical location or soil type and it showed a wide applicability and consistency across various plant species and organs. From an analytical perspective, the method is therefore considered ready for further testing on additional plant species and implementation as a routine tool for authentication of organic vegetables. 


\section{Acknowledgements}

Financial support was obtained from: i) the Danish Council for Independent Research - Technology and Production Sciences via the COM-ISO project (DFF-1337-00055), ii) the CORE Organic II Funding Bodies, being partners of the FP7 ERANet Project, CORE Organic II (Coordination of European Transnational Research in Organic Food and Farming systems, Project No. 249667) via the AuthenticFood project, iii) the Ministry of Food, Agriculture and Fisheries, Denmark, via the OrgTrace research project (3304-FOJO-05-45-01), which was coordinated by the International Centre for Research in Organic Food Systems (ICROFS) and, iv) the European Union Seventh Framework Programme (FP7) under the grant agreement number 613688 (Foodlntegrity). J. E. Olesen and colleagues from the CropSys project are acknowledged for production of plant material at the field trial stations Flakkebjerg, Foulum and Jyndevad, Aarhus University. K. Thorup-Kristensen and colleagues from the VegQure project are acknowledged for production of plant material at the field trial station Aarslev, Aarhus University. We also thank student assistants, junior scientists and technicians from the COM-ISO, AuthenticFood, OrgTrace and FoodIntegrity projects for assistance with sampling, sample preparation and analysis. Joy Matthews and colleagues from the Stable Isotope Facility at University of California, Davis are acknowledged for assistance with oxygen isotope analysis of bulk plant tissue, sulphate and nitrate.

\section{Conflict of Interest}

All authors declare that they have no conflict of interest. 


\section{References}

Barbour, M. M. (2007). Stable oxygen isotope composition of plant tissue: a review. Functional Plant Biology, 34(2), 83-94.

Bateman, A. S., \& Kelly, S. D. (2007). Fertiliser nitrogen isotope signatures. Isotopes in Environmental and Health Studies, 43(3), 237-247.

Bateman, A. S., Kelly, S. D., \& Woolfe, M. (2007). Nitrogen Isotope Composition of Organically and Conventionally Grown Crops. Journal of Agricultural and Food Chemistry, 55(7), 2664-2670.

Blake-Kalff, M. M. A., Harrison, K. R., Hawkesford, M. J., Zhao, F. J., \& McGrath, S. P. (1998). Distribution of Sulfur within Oilseed Rape Leaves in Response to Sulfur Deficiency during Vegetative Growth. Plant Physiology, 118(4), 1337-1344.

Blake, R. E., Surkov, A. V., Böttcher, M. E., Ferdelman, T. G., \& Jørgensen, B. B. (2006). Oxygen isotope composition of dissolved sulfate in deep-sea sediments: eastern equatorial Pacific Ocean. Proceedings of the Ocean Drilling Programm, Scientific Results, 201, 1-24.

Bowen, G. J., \& Wilkinson, B. (2002). Spatial distribution of $\delta 180$ in meteoric precipitation. Geology, 30(4), 315-318.

Camin, F., Moschella, A., Miselli, F., Parisi, B., Versini, G., Ranalli, P., \& Bagnaresi, P. (2007). Evaluation of markers for the traceability of potato tubers grown in an organic versus conventional regime. Journal of the Science of Food and Agriculture, 87(7), 1330-1336.

Capuano, E., Boerrigter-Eenling, R., Veer, G., \& Ruth Saskia, M. (2012). Analytical authentication of organic products: an overview of markers. Journal of the Science of Food and Agriculture, 93(1), 12-28.

Casciotti, K. L., Sigman, D. M., Hastings, M. G., Böhlke, J. K., \& Hilkert, A. (2002). Measurement of the Oxygen Isotopic Composition of Nitrate in Seawater and Freshwater Using the Denitrifier Method. Analytical chemistry, 74(19), 4905-4912.

Choi, W.-J., Kwak, J.-H., Lim, S.-S., Park, H.-J., Chang, S. X., Lee, S.-M., Arshad, M. A., Yun, S.-I., \& Kim, H.-Y. (2017). Synthetic fertiliser and livestock manure differently affect $\delta 15 \mathrm{~N}$ in the agricultural landscape: A review. Agriculture, Ecosystems \& Environment, 237, 1-15.

Dangour, A. D., Dodhia, S. K., Hayter, A., Allen, E., Lock, K., \& Uauy, R. (2009). Nutritional quality of organic foods: a systematic review. The American Journal of Clinical Nutrition, 90(3), 680685.

Devlieghere, F., De Henauw, S., Baert, K., De Meulenaer, B., Vandekinderen, I., Hoefkens, C., Verbeke, W., Sioen, I., \& Van Camp, J. (2009). A literature-based comparison of nutrient and contaminant contents between organic and conventional vegetables and potatoes. British Food Journal, 111(10), 1078-1097.

Fischer, R., \& Rhinehammer, R. (1953). Rapid precipitation of barium sulfate. Analytical chemistry, 25(10), 1544-1548.

Florin, T. H. J., Neale, G., Goretski, S., \& Cummings, J. H. (1993). The Sulfate Content of Foods and Beverages. Journal of Food Composition and Analysis, 6(2), 140-151.

Hawkesford, M. J., \& De Kok, L. J. (2006). Managing sulphur metabolism in plants. Plant, Cell \& Environment, 29(3), 382-395

Junk, G., \& Svec, H. J. (1958). The absolute abundance of the nitrogen isotopes in the atmosphere and compressed gas from various sources. Geochimica et Cosmochimica Acta, 14(3), 234243. 
Kang, P.-G., Mayer, B., \& Mitchell, M. J. (2012). Comparison of sample preparation methods for stable isotope analysis of dissolved sulphate in forested watersheds. Isotopes in Environmental and Health Studies, 48(3), 410-420.

Kelly, S., \& Mihailova, A. (2017). Chapter 12: Organic food authenticity. In J. F. Carter \& L. A. Chesson (Eds.), Food Forensics: Stable Isotopes as a Guide to Authenticity and Origin (pp. 273-302).

Kroopnick, P., \& Craig, H. (1972). Atmospheric Oxygen: Isotopic Composition and Solubility Fractionation. Science, 175(4017), 54-55.

Laursen, K. H., Bontempo, L., Camin, F., \& Roßmann, A. (2016). Advances in Isotopic Analysis for Food Authenticity Testing. 227-252.

Laursen, K. H., Mihailova, A., Kelly, S. D., Epov, V. N., Berail, S., Schjoerring, J. K., Donard, O. F., Larsen, E. H., Pedentchouk, N., Marca-Bell, A. D.,Halekoh, U., Olesen, J. E., \& Husted, S. (2013). Is it really organic? - Multi-isotopic analysis as a tool to discriminate between organic and conventional plants. Food Chem, 141(3), 2812-2820.

Laursen, K. H., Schjoerring, J. K., Kelly, S. D., \& Husted, S. (2014). Authentication of organically grown plants - advantages and limitations of atomic spectroscopy for multi-element and stable isotope analysis. TrAC Trends in Analytical Chemistry, 59, 73-82.

Laursen, K. H., Schjoerring, J. K., Olesen, J. E., Askegaard, M., Halekoh, U., \& Husted, S. (2011). Multielemental Fingerprinting as a Tool for Authentication of Organic Wheat, Barley, Faba Bean, and Potato. Journal of Agricultural and Food Chemistry, 59(9), 4385-4396.

Lernoud, J., \& Willer, H. (2019). The World of Organic Agriculture. Statistics and Emerging Trends 2019. Research Institute of Organic Agriculture (FiBL) \& IFOAM - Organics International.

Mariotti, A., Mariotti, F., Champigny, M.-L., Amarger, N., \& Moyse, A. (1982). Nitrogen Isotope Fractionation Associated with Nitrate Reductase Activity and Uptake of $\mathrm{NO}_{3}{ }^{-}$by Pearl Millet. Plant Physiology, 69(4), 880-884.

Mark, A. B., Kapolna, E., Laursen, K. H., Halekoh, U., Rasmussen, S. K., Husted, S., Larsen, E. H., Bugel, S. (2013). Consumption of organic diets does not affect intake and absorption of zinc and copper in men - evidence from two cross-over trials. Food \& Function, 4(3), 409-419.

Mayer, B., Fritz, P., Prietzel, J., \& Krouse, H. R. (1995). The use of stable sulfur and oxygen isotope ratios for interpreting the mobility of sulfate in aerobic forest soils. Applied Geochemistry, 10(2), 161-173.

Mihailova, A., Pedentchouk, N., \& Kelly, S. D. (2014). Stable isotope analysis of plant-derived nitrate - Novel method for discrimination between organically and conventionally grown vegetables. Food Chem, 154, 238-245.

Olesen, J. E., Askegaard, M., \& Rasmussen, I. A. (2000). Design of an Organic Farming Crop-Rotation Experiment. Acta Agriculturae Scandinavica, Section B - Soil \& Plant Science, 50(1), 13-21.

Paolini, M., Ziller, L., Laursen, K. H., Husted, S., \& Camin, F. (2015). Compound-Specific $\delta^{15} \mathrm{~N}$ and $\delta 13 \mathrm{C}$ Analyses of Amino Acids for Potential Discrimination between Organically and Conventionally Grown Wheat. Journal of Agricultural and Food Chemistry, 63(25), 58415850 .

Reganold, J. P., \& Wachter, J. M. (2016). Organic agriculture in the twenty-first century. Nature Plants, 2, 15221.

Reuter, D., \& Robinson, J. (1997). Plant Analysis: An Interpretation Manual: CSIRO Publishing.

Rosen, C. J. (2005). Cabbage yield and glucosinolate concentrations as affected by nitrogen and sulfur fertility. HortScience, 40(5), 1493-1498. 
Schmidt, H.-I., Roßmann, A., Voerkelius, S., Schnitzler, W. H., Georgi, M., Graßmann, J., Zimmermann, G., \& Winkler, R. (2005). Isotope characteristics of vegetables and wheat from conventional and organic production. Isotopes in Environmental and Health Studies, 41(3), 223-228.

Sigman, D. M., Casciotti, K. L., Andreani, M., Barford, C., Galanter, M., \& Böhlke, J. K. (2001). A Bacterial Method for the Nitrogen Isotopic Analysis of Nitrate in Seawater and Freshwater. Analytical chemistry, 73(17), 4145-4153.

Tamme, T., Reinik, M., \& Roasto, M. (2010). Chapter 21 - Nitrates and Nitrites in Vegetables: Occurrence and Health Risks. In R. R. Watson \& V. R. Preedy (Eds.), Bioactive Foods in Promoting Health (pp. 307-321). San Diego: Academic Press.

Tanz, N., \& Schmidt, H.-L. (2010). $\delta^{34}$ S-Value Measurements in Food Origin Assignments and Sulfur Isotope Fractionations in Plants and Animals. Journal of Agricultural and Food Chemistry, 58(5), 3139-3146.

Tcherkez, G., \& Tea, I. (2013). ${ }^{32} \mathrm{~S} /{ }^{34} \mathrm{~S}$ isotope fractionation in plant sulphur metabolism. New Phytologist, 200(1), 44-53.

Thorup-Kristensen, K., Dresbøll, D. B., \& Kristensen, H. L. (2012). Crop yield, root growth, and nutrient dynamics in a conventional and three organic cropping systems with different levels of external inputs and $\mathrm{N}$ re-cycling through fertility building crops. European Journal of Agronomy, 37(1), 66-82.

Vitòria, L., Otero, N., Soler, A., \& Canals, A. (2004). Fertiliser characterization: Isotopic data (N, S, O, C, and Sr). Environmental Science and Technology, 38(12), 3254-3262.

Xue, D., Botte, J., De Baets, B., Accoe, F., Nestler, A., Taylor, P., Van Cleemput, O., Berglund, M., \& Boeckx, P. (2009). Present limitations and future prospects of stable isotope methods for nitrate source identification in surface- and groundwater. Water Research, 43(5), 1159-1170. 

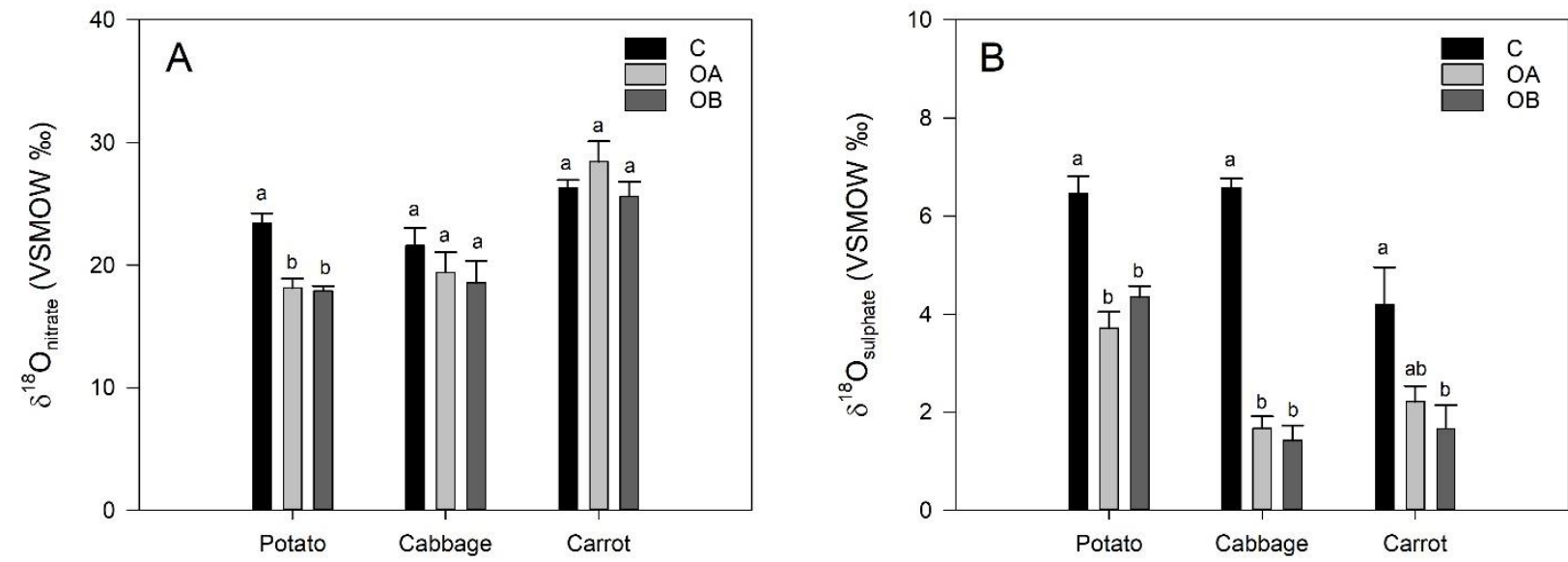

Fig. 1. Stable isotope ratio values for oxygen in (A) nitrate $-\delta^{18} \mathrm{O}_{\text {nitrate }}$ and $(B)$ sulphate $-\delta^{18} \mathrm{O}_{\text {sulphate }}$ of potato tubers, cabbage heads and carrot roots from three cropping systems: $\mathrm{C}$ (conventional, black bars), OA (organic animal manure, light grey bars), OB (organic green manure, dark grey bars). Bars represent mean values + standard error of the mean (potato $n=12$, carrot $n=6$, cabbage $n=6$ ). Different letters within each vegetable in each figure show significant differences $(p<0.05)$, one-way ANOVA with post-hoc Tukey HSD. 

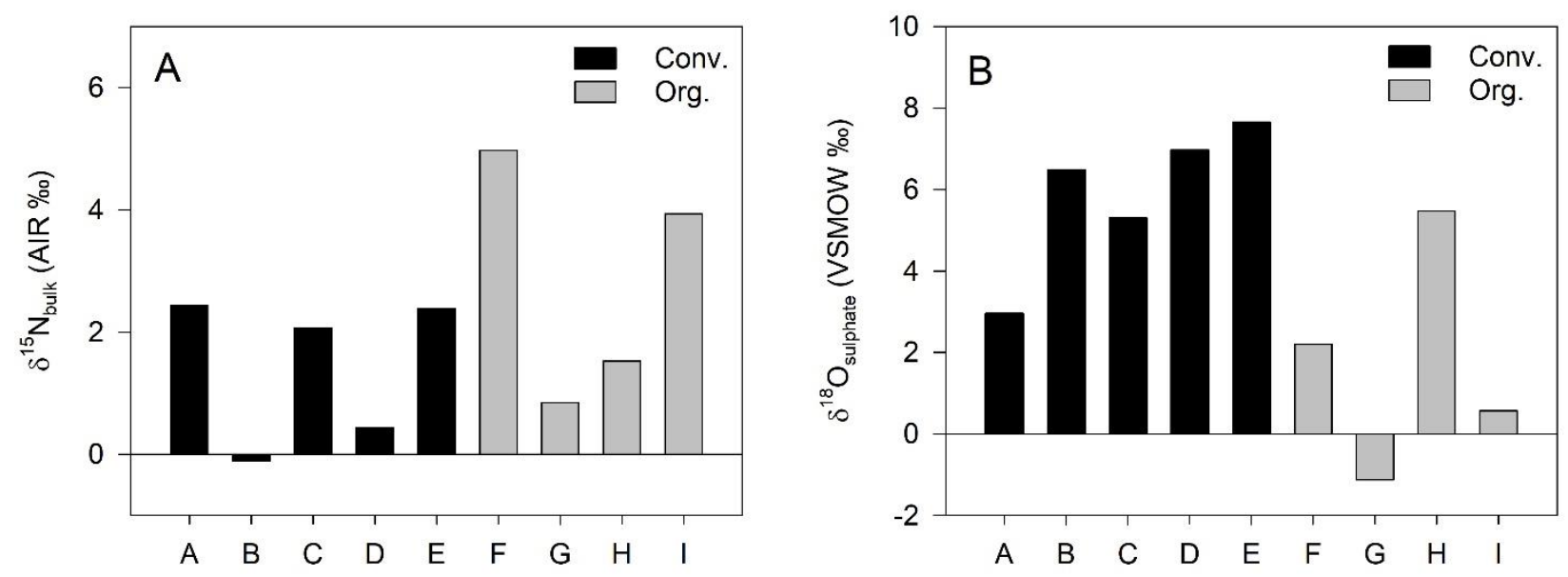

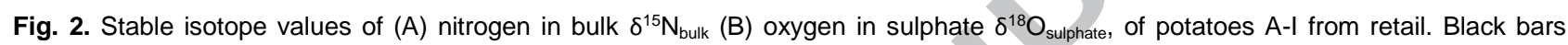
represent potatoes A-E sold as conventional from Denmark (Conv.). Grey bars represent potato tubers F-I sold as Danish organic (Org.). 
Table 1: Elemental $(\mathrm{C}, \mathrm{N}, \mathrm{S})$, anion $\left(\mathrm{NO}_{3}{ }^{-}, \mathrm{SO}_{4}{ }^{2-}\right)$ content and stable isotope ratios $\left(\delta^{13} \mathrm{C}_{\text {bulk }}, \delta^{15} \mathrm{~N}_{\text {bulk }}, \delta^{18} \mathrm{O}_{\text {bulk, }}, \delta^{15} \mathrm{~N}_{\text {nitrate }}\right)$ of field-grown potato, cabbage and carrot.

\begin{tabular}{|c|c|c|c|c|c|c|c|c|c|c|c|}
\hline Vegetable & System & $\mathrm{n}$ & $\begin{array}{l}\mathrm{C} \\
(\%)\end{array}$ & $\begin{array}{l}N \\
(\%)\end{array}$ & $\begin{array}{l}\mathrm{S} \\
(\%)\end{array}$ & $\begin{array}{l}\mathrm{NO}_{3}{ }^{-} \\
(\mathrm{mg} / \mathrm{g} \mathrm{DW})\end{array}$ & $\begin{array}{l}\mathrm{SO}_{4}{ }^{2-} \\
(\mathrm{mg} / \mathrm{g} \mathrm{DW})\end{array}$ & $\begin{array}{l}\delta^{13} \mathrm{C}_{\text {bulk }} \\
(\%)\end{array}$ & $\begin{array}{l}\delta^{15} N_{\text {bulk }} \\
(\%)\end{array}$ & $\begin{array}{l}\delta^{18} \mathrm{O}_{\text {bulk }} \\
(\% \circ)\end{array}$ & $\begin{array}{l}\delta^{15} \mathrm{~N}_{\text {nitrate }} \\
(\% \circ)\end{array}$ \\
\hline \multirow[t]{3}{*}{ Potato } & $\mathrm{C}$ & 12 & $40.8 \pm 0.4$ & $1.5 \pm 0.1$ & $0.1 \pm 0.0$ & $0.3 \pm 0.0^{\mathrm{ab}}$ & $3.3 \pm 0.2^{b}$ & $-27.2 \pm 0.3$ & $1.3 \pm 0.3^{b}$ & $26.6 \pm 0.3$ & $20.7 \pm 0.8^{b}$ \\
\hline & $\mathrm{OA}$ & 12 & $41.1 \pm 0.2$ & $1.6 \pm 0.1$ & $0.2 \pm 0.0$ & $0.4 \pm 0.1^{\mathrm{a}}$ & $3.4 \pm 0.1^{b}$ & $-26.5 \pm 0.2$ & $4.5 \pm 0.4^{a}$ & $26.7 \pm 0.4$ & $23.4 \pm 0.7^{a}$ \\
\hline & OB & 12 & $41.1 \pm 0.2$ & $1.4 \pm 0.0$ & $0.2 \pm 0.0$ & $0.2 \pm 0.0^{b}$ & $4.1 \pm 0.2^{a}$ & $-26.6 \pm 0.3$ & $1.7 \pm 0.4^{b}$ & $26.8 \pm 0.4$ & $21.2 \pm 0.7^{\mathrm{ab}}$ \\
\hline \multirow[t]{3}{*}{ Cabbage } & $\mathrm{C}$ & 6 & $38.5 \pm 0.1$ & $1.9 \pm 0.1$ & $0.6 \pm 0.0$ & $2.2 \pm 0.5$ & $7.7 \pm 0.7$ & $-24.0 \pm 0.1$ & $2.9 \pm 0.6^{b}$ & $25.5 \pm 0.0$ & $23.7 \pm 1.3$ \\
\hline & OA & 6 & $38.6 \pm 0.1$ & $1.8 \pm 0.1$ & $0.6 \pm 0.0$ & $2.6 \pm 0.8$ & $8.0 \pm 0.2$ & $-23.9 \pm 0.1$ & $7.5 \pm 0.4^{a}$ & $25.6 \pm 0.1$ & $26.9 \pm 1.5$ \\
\hline & OB & 6 & $38.7 \pm 0.1$ & $1.8 \pm 0.1$ & $0.6 \pm 0.0$ & $3.0 \pm 1.2$ & $7.7 \pm 1.2$ & $-23.8 \pm 0.1$ & $4.2 \pm 0.3^{b}$ & $25.4 \pm 0.1$ & $24.0 \pm 1.6$ \\
\hline \multirow[t]{3}{*}{ Carrot } & $\mathrm{C}$ & 6 & $39.4 \pm 0.1$ & $0.9 \pm 0.0$ & $0.1 \pm 0.0$ & $0.4 \pm 0.0^{\mathrm{a}}$ & $1.9 \pm 0.2$ & $-27.8 \pm 0.1$ & $2.7 \pm 0.4^{b}$ & $24.2 \pm 0.1$ & $27.9 \pm 0.4^{b}$ \\
\hline & $\mathrm{OA}$ & 6 & $39.5 \pm 0.1$ & $0.7 \pm 0.0$ & $0.1 \pm 0.0$ & $0.2 \pm 0.0^{b}$ & $1.8 \pm 0.1$ & $-27.8 \pm 0.2$ & $5.2 \pm 0.7^{\mathrm{a}}$ & $24.1 \pm 0.2$ & $36.3 \pm 1.9^{a}$ \\
\hline & $\mathrm{OB}$ & 6 & $39.5 \pm 0.2$ & $0.8 \pm 0.0$ & $0.1 \pm 0.0$ & $0.2 \pm 0.0^{\mathrm{b}}$ & $1.7 \pm 0.1$ & $-27.8 \pm 0.2$ & $3.9 \pm 0.8^{b}$ & $24.4 \pm 0.1$ & $32.1 \pm 1.5^{\mathrm{ab}}$ \\
\hline
\end{tabular}

Values are the mean \pm standard error of the mean. The number of biological replicates is shown by $\mathrm{n}$. Three vegetable growing systems: $C$ (conventional system with synthetic fertilisers), OA (organic system with animal manure), OB (organic system green manure). Different letters within each vegetable and variable show statistical significant differences $(p<0.05)$, one-way ANOVA with post-hoc Tukey HSD. 
Table 2: Content of water-soluble sulphate and its stable oxygen isotope composition in selected fertilisers used in the field study.

\begin{tabular}{lllllll}
\hline Fertiliser & $\begin{array}{l}\text { Fertilizer } \\
\text { type }\end{array}$ & $\begin{array}{l}\text { Fertilized } \\
\text { vegetable }\end{array}$ & $\begin{array}{l}\text { Cropping } \\
\text { system }\end{array}$ & Location & $\begin{array}{l}\mathrm{SO}_{4}{ }^{2-} \\
(\%)\end{array}$ & $\begin{array}{l}\delta^{18} \mathrm{O}_{\text {sulphate }} \\
(\%)\end{array}$ \\
\hline Vinasse & Organic & Potato & OA, OB & Flk & 3.2 & 9.9 \\
& & & & Fou & 3.5 & 10.4 \\
NPK 14-5-18 & Synthetic & Potato & C & Jyn & 3.4 & 10.0 \\
& & & & Flk & 16.7 & 14.2 \\
NPK 21-3-10 & Synthetic & Carrot, Cabbage & C & Fou & 13.8 & 13.6 \\
\hline
\end{tabular}

Three cropping systems: C (conventional), OA (organic animal manure), OB (organic green manure). Flk, Fou, Jyn and Aar stand for the production locations in Denmark where the fertilizers were used, viz. Flakkebjerg, Foulum, Jyndevad and Aarslev, respectively. NPK stands for nitrogen-phosphorus-potassium fertilizer, whereas the numbers represent each respective nutrient \% by weight. 
Table 3: Classification of retail potatoes on the basis of $\delta^{15} \mathrm{~N}_{\text {bulk }}$ and $\delta^{18} \mathrm{O}_{\text {sulphate }}$ threshold values and quadratic discriminant analysis (QDA).

\begin{tabular}{|c|c|c|c|c|c|}
\hline \multicolumn{2}{|c|}{ Retail potato } & \multirow{2}{*}{$\begin{array}{l}\delta^{15} \mathrm{~N}_{\text {bulk }} \text { threshold } 4.3 \% 0^{\mathrm{a}} \\
\text { Predicted system }\end{array}$} & \multirow{2}{*}{$\begin{array}{l}\delta^{18} \mathrm{O}_{\text {sulphate }} \text { threshold } 5.1 \%{ }^{\mathrm{b}} \\
\text { Predicted system }\end{array}$} & \multicolumn{2}{|c|}{ QDA predicted system probability (\%) } \\
\hline ID & Package label & & & Conventional & Organic \\
\hline A & Conventional & Conventional & Organic & - & 100 \\
\hline B & Conventional & Conventional & Conventional & 99 & 1 \\
\hline C & Conventional & Conventional & Conventional & 9 & 91 \\
\hline D & Conventional & Conventional & Conventional & 100 & \\
\hline $\mathrm{E}$ & Conventional & Conventional & Conventional & 100 & \\
\hline $\mathrm{F}$ & Organic & Organic & Organic & - & 100 \\
\hline G & Organic & Conventional & Organic & - & 100 \\
\hline $\mathrm{H}$ & Organic & Conventional & Conventional & 43 & \\
\hline I & Organic & Conventional & Organic & - & 100 \\
\hline
\end{tabular}

${ }^{a}$ Threshold $\delta^{15} \mathrm{~N}_{\text {bulk }}$ value proposed by (Camin et al., 2007). ${ }^{\text {b}}$ Threshold $\delta^{18} \mathrm{O}_{\text {sulphate }}$ proposed in this study based on field trial results. The QDA model was calculated from $\delta^{15} \mathrm{~N}_{\text {bulk }}$ and $\delta^{18} \mathrm{O}_{\text {sulphate }}$ of field trial potatoes and used to predict the growth system (conventional, organic) of retail potatoes. 